\title{
Recent record of the Phalakron Plain Plushblue Flos apidanus phalakron (Lepidoptera: Lycaenidae) in South Sumatra after 91 years break
}

\author{
Muhammad Iqbal $^{*}$, Andes Syahputra', Arum Setiawan ${ }^{3}$, Indra Yustian ${ }^{4}$ \\ ${ }^{1}$ Biology Program, Faculty of Mathematics and Natural Sciences, Sriwijaya University, Palembang \\ ${ }^{2}$ Student of Department of Biology, Faculty of Mathematics and Natural Sciences, Sriwijaya \\ University, Indralaya \\ ${ }^{3,4}$ Department of Biology, Faculty of Mathematics and Natural Sciences, Sriwijaya University, \\ Indralaya
}

*email:kpbsos26@yahoo.com

Article Info

Key word:

Flos apidanus

Plain Plushblue

Rediscovery

Rhopalocera

South Sumatra

Article history:

Received: 03/05/2020

Revised: 07/08/2020

Accepted: 10/08/2020

\begin{abstract}
An individual of Phalakron Plain Plushblue Flos apidanus phalakron was observed and photographed on 17 March 2020 at campus Sriwijaya University, Indralaya, South Sumatra province. In South Sumatra, this butterfly only known from a historical record in 1929. The recent observation of Flos apidanus phalakron in Indralaya represent a new record for South Sumatra province after 91 years break.
\end{abstract}

Copyright (C) 2020 Universitas Islam Negeri Raden Fatah Palembang. All Right Reserved

\section{Introduction}

Family Lycaenidae (lycaenid butterflies) are large group of butterflies comprise more 5.000 species (Holloway et al., 2012). These groups are small to medium sized butterflies, and many are rare or have localized distribution (Ek-Amnuay, 2012). Generally, the males are more highly coloured than females (Fleming, 1983). Many more undoubtedly remain to be discovered as most of the tropical species spend their entire lives undetected in the rainforest canopy (Hoskins, 2015).

Flos is one genus of family Lycaenidae that having a broad dark band on underwing and hindwing without a tail or with a weakly dentated or rounded tail at the marginal border (Ek-amnuay, 2012). There are six species of genus Flos in Sumatra, including Flos apidanus, Flos anniella, Flos bungo, Flos diardi, Flos fulgida and Flos morphina (d'Abrera, 1986; Savela, 2020). This genus under subfamily Theclinae, a large subfamily of family Lycaenidae, with many species of varying patterns and colour (Kirton, 2014). Subfamily Theclinae occurs on and continents and in all habitats, including moors, grassland, deciduous woodlands and tropical rainforests (Hoskins, 2015).

As the second largest island of Indonesia, Sumatra has rich animal diversity (Whitten et al., 2000). The island had at least 
756 species of butterflies (de Niceville \& Martin, 1896), but this number must be increased recently. The Plain Plusblue Flos apidanus is one species of butterfly that occur in Sumatra (d'abrera, 1986). In 1914, few specimens of Flos apidanus from Sumatra were described as a distinct subspecies with original name Arhopala apidanus phalakron (Fruhstorfer, 1914). A comprehensive study of the genus Arhopala group of family Lycaenidae redesigned Amblypodia apidanus to Flos apidanus, then Flos apidanus phalakron was named for this Sumatran butterfly (Evans, 1957).

This paper describe a recent finding of Flos apidanus phalakron in Indralaya, South Sumatra province. The occurrence of Flos apidanus phalakron from Indralaya is represent a recent record in South Sumatra province after 91 years break.

\section{Materials and Methods}

On 17 March 2020, a lycaenid butterfly was observed and photographed at arboretum of campus Sriwijaya University, Indralaya $\quad\left(03^{\circ} 14^{\prime} 29^{\prime \prime} \mathrm{S}, \quad 104^{\circ} 39^{\prime} 54^{\prime \prime} \mathrm{E}\right)$. Unfortunately, the butterfly is unable to caught and no specimen was preserved. However, distinct morphological features of the butterfly were clearly seen from some pictures taken from prosumer Fuji Film Pinefix S1 with 50x zoom lens camera. The butterfly was identified to species level with appropriate butterfly guides.

\section{Results and Discussion}

The lycaenid butterfly found at campus of Sriwijaya University in Indralaya has small-medium butterfly size (c. $20 \mathrm{~mm}$ of forewing length, and $34 \mathrm{~mm}$ of wingspan), hindwing with weakly dentated, underwing is pale yellowish brown, with a dark reddish brown area at bases of hindwing, forewing discal and postdiscal bands evenly curved, hindwing with irregular discal gray bands from midcosta to the mid dorsum and darker towards the borders (Figure 1). These characters are fitted well to characters of Flos apidanus in selected references (d'Abrera, 1986; Corbet \& Pendlebury, 1992; Khoon, 2010; Ek-Amnuay, 2012).
There are two subspecies of Flos apidanus in Sumatra, Flos apidanus phalakron (Fruhstorfer, 1914) and Flos apidanus saturatus (Snellen, 1890). The Flos apidanus phalakron is distributed from Weh Island (Aceh) to Palembang (South Sumatra), and Flos apidanus saturatus distributed in Riau archipelagos to Bangka Belitung islands (Snellen, 1890; Fruhstorfer, 1914; Toxopeus, 1929; d'Abrera, 1986).

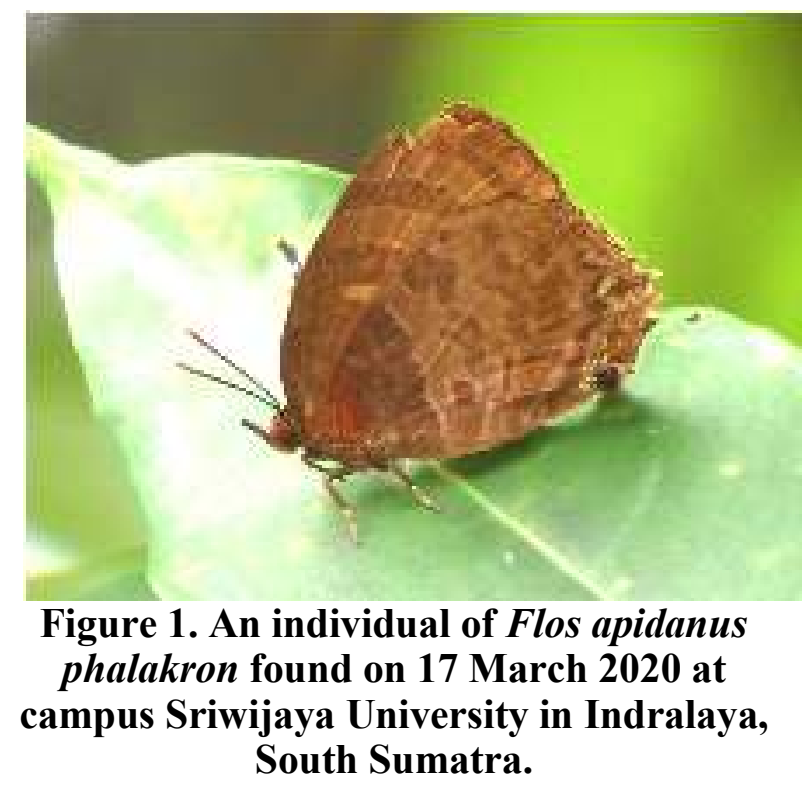

Record of Flos apidanus at campus Sriwijaya University in Indralaya is an unexpected record. There are 40 species of butterflies at the campus Sriwijaya University of Indralaya, but Flos apidanus was absent from the list (Lamin et al., 2016). Flos apidanus is usually absent from many lists on the study of butterflies diversity in Sumatra (eg. Rahayu \& Basukriadi, 2012; Rusman et al., 2016; Panjaitan et al., 2019; Pratiwi \& Dahelmi, 2019; Setiawan et al., 2020). The known records of Flos apidanus in Sumatra after Toxopeus 1929 are from Brastagi, North Sumatra, on 25 March 1973; from Batam island, Riau Archipelagos, on 31 May 2008; Mount Betung, Lampung, between 1998 to 2011; Puhawang island, Lampung, in August 2013; Gita Persada, Lampung, in 2019 (Chaiyen, 2008; Soekardi, 2011; Soekardi, 2013; Teshirogi et al., 2016; Gita Persada 2019). The records above suggest Flos apidanus is a rare species in Sumatra. 
Recent observation of Flos apidanus phalakron at the campus of Sriwijaya University in Indralaya is a recent record of this subspecies in South Sumatra province after 91 years break. This subspecies different from other subspecies by having much duller with the purplish cast of the hindwing missing, and the tornus of the hindwing appear to extensive green metallic green scaling (d'Abrera 1986). This subspecies has been known occur in Palembang based on a historical record in 1929 (Toxopeus 1929), but no information available since this report. The host plants known for Flos apidanus are plant from family Lythraceae and Myrtaceae (Robinson et al. 2001). The plants from both families are relatively able to find in Sumatra. Further study to monitoring the occurrence of Flos apidanus phalakron in Sumatra is needed, to looking at spatial distributions and trends of population in the future.

\section{Conclusion}

Recent observation Flos apidanus phalakron at campus Sriwijaya University in Indralaya is a rediscovery record in South Sumatra province after the first time reported in 1929. This recent observation is represent a second record for South Sumatra after 91 years break.

\section{Acknowledgment}

We thank Motoko Fujita (Kyoto University) who help and kindly share some references related to Flos apidanus. We are very grateful to anonymous reviewers for comments on our preliminary draft to make this paper improve.

\section{References}

Chaiyen. 2008. Plushblue. Available: http://jalankenari.blogspot.com/2008/05/ (2 May 2020).

Corbet, A.S. \& Pendlebury, H.M. 1992. The Butterflies of the Malay Peninsula. Fourth Edition. Malayan Nature Society, Kuala Lumpur.

d'Abrera, B. 1986. Butterflies of the Oriental region, part III. Hill House Publishers, Victoria.
De Niceville, L. \& L. Martin. 1896. A list of the butterflies of Sumatra, with especial reference to the species occurring in the north-east of the Island. Journal of the Asiatic Society of Bengal [II], 64, 357555.

Ek-Amnuay, P. 2012. Butterflies of Thailand. Baan Lae Suan Amarin Printing and Publishing, Bangkok.

Evans, W.H. 1957. A revision of the Arhopala group of the Oriental Lycaenidae. Bulletin of the British Museum Natural History Entomology, 5(3), 83-141.

Fleming, W.A. 1983. Butterlies of west Malaysia and Singapore, second edition. Longman, Malaysia.

Fruhstorfer, H. 1914. Neue Arhopala Rassen. Deutsche entomologische Zeitschrift Iris, 28(2), 121-137.

Gita Persada. 2019. Species checklist. Available:

http://gitapersada.weebly.com/checklist. html (24 April 2020).

Holloway, J.D., Kibby, G. \& Peggie, D. 2001. The families of Malesian moths and butterflies. Brill, Leiden.

Hoskins, A. 2015. Butterflies of the world. Reed New Holland Publishers Pty Ltd, London.

Khoon, S.K. 2010. A field guide to the butterflies of Singapore. Ink On Paper Communications Pte Ltd, Singapore.

Kirton, L.G. 2014. A naturalist's guide to the butterflies of Peninsular Malaysia, Singapore and Thailand. John Beaufoy Publishing, London.

Lamin, S., Nirmila Sari, N. \& Setiawan, D. 2016. Distribution and diversity of butterflies (Lepidoptera: Rhopalocera) in campus area Indralaya Sriwijaya University of South Sumatra. Biovalentia, 2(2), 123-131.

Panjaitan, R., Hidayat, P., Peggie, D., Buchori, D., Scheu, S. \& Drescher, J. 2019. The Butterflies of Eastern JambiAn EFForTS Field Guide. Version 1.0, June 2019. Johann Friedrich Blumenbach Institute for Zoology and Anthropology, University of Göttingen.

Pratiwi, E.A. \& Dahelmi. 2019. Inventory of butterflies (Lepidoptera: Rhopalocera) in 
the Padang City of Waterfall Area, West Sumatra. Bioconcetta, 5(2), 85-92.

Rahayu, S.E. \& Basukriadi, A. 2012. The Richness and Diversity of Butterflies (Lepidoptera; Rhopalocera) in the Urban Forest of Muhammad Sabki, Jambi Province, Indonesia. Biospecies, 5(2), 40-48.

Robinson, G.S., Ackery, P.R., Kitching, I.J., Beccaloni, G.W. \& Hernandez, L.M. 2001. Hostplants of the Moth and Butterfly Caterpillars of the Oriental Region. The Natural History Museum, London.

Rusman, R.,T. Atmowidi and D. Peggie. 2016. Butterflies (Lepidoptera: Papilionoidea) of Mount Sago,West Sumatra: Diversity and Flower Preference. Hayati Journal of Biosciences, 23: 132-137.

Savela, M. 2020. Flos Doherty, 1889. Available:

http://ftp.funet.fi/index/Tree_of_life/inse cta/lepidoptera/ditrysia/papilionoidea/lyc aenidae/theclinae/flos/ (2 May 2020).

Setiawan, D., I. Aprillia, M. Iqbal, G. Pragustiandi, A. Setiawan and I. Yustian. 2020. First record of Hagen's batwing Atrophaneura hageni (Rogenhofer, 1889) (Lepidoptera: Papiolinidae) in southern Sumatra, Indonesia. Ecologica Montenegrina, 28, 26-30.

Snellen, P.C.T. 1890. Aanteekeningen over de Lepidoptera van het Eiland Belitoeng. Tijdschrift voor Entomologie, 33(4), 279-310.

Soekardi, H. 2011. Sumatran Butterflies Conservation in Mount Betung, Lampung. In: Sancayaningsih, R.P., Sembiring, L., Mulyati., Semiarti, E., Soetarto, E.S., Austin, C. \& Bessho, Y. Preceeding International Conference on Biological Science Faculty of Biology Universitas Gadjah Mada 2011 (ICBS BIO-UGM 2011). Faculty of Biology Gadjah Mada University. p 167-174.

Soekardi, H. 2013. Survei keanekaragaman kupu-kupu di beberapa pulau kecil, Teluk Lampung. Fakultas Matematika dan Ilmu Pengetahuan Alam Universitas Lampung, Lampung.
Teshirogi, M., Harada, M., Ito, H., Harada, K., Tanio, T., Ito, Y., \& Yago, M. 2016. Catalogue of the Suguru Igarashi Insect Collection, The University Museum, The University of Tokyo, Part IV. Lepidoptera: Lycaenidae \& Riodinidae. Available: http://umdb.um.utokyo.ac.jp/DDoubutu/igarashi04/en/cab inet2.php? Number $=3029 \&$ skip $=0 \& \max$ $=200$ ( 2 May 2020).

Toxopeus, L.J. 1929. Beschreibung einiger Schmetterlinge (Riodinidae und Lycaenidae) von Pulu Weh bei Sumatra. (Lycaenidae Australasiae V). Tijdschrift voor entomologie, 72(3-4), 204-214.

Whitten, T., Damanik, S.J., Anwar, J. \& Hisyam, N. 2000. The ecology of Sumatra. Singapore, Periplus. 